Feasibility and initial psychometric properties of the Observe, Reflect, Improve Children's Learning Tool (ORICL) for Early Childhood Services: A tool for building capacity in infant and toddler educators

Kate E. Williams ${ }^{1}$, Magdalena Janus ${ }^{2}$, Linda J. Harrison ${ }^{3}$, Sandie Wong ${ }^{3}$, Sheena Elwick ${ }^{4}$, Laura McFarland ${ }^{4}$

1. Centre for Child \& Family Studies and School of Early Childhood and Inclusive Education Queensland University of Technology, Australia. ORCID 0000-0001-8983-5503

2. Offord Centre for Child Studies, Department of Psychiatry and Behavioural Neurosciences, McMaster University, Hamilton ON, Canada. ORCID 0000-0002-9500-6776

3. Macquarie School of Education, Macquarie University, Australia

Linda Harrison ORCID 0000-0003-3835-6283

Sandie Wong ORCID 0000-0003-3246-0717

4. School of Education, Charles Sturt University, Australia

Sheena Elwick ORCID 0000-0003-2942-6278

Laura McFarland ORCID 0000-0003-2051-7237

Corresponding author: Kate E. Williams, QUT, Level 4 E Block, Victoria Park Road, Kelvin Grove,Qld, Australia, 4059,k15.williams@qut.edu.au,Ph +61 731383080

The data that support the findings of this study are not available due to ethical restrictions.

This study was approved by the Human Research Ethics Committee of Charles Sturt University. Approval number 1800000758.

There are no funding or conflicts of interest to disclose. 


\title{
Feasibility and initial psychometric properties of the Observe, Reflect, Improve Children's Learning Tool (ORICL) for Early Childhood Services: A tool for building capacity in infant and toddler educators.
}

\begin{abstract}
Child observation is a critical component of quality pedagogical practice in early childhood education and care (ECEC). Yet there are very few tools that support educators to systematically undertake observations to better understand the individual experiences of very young children within ECEC services. The ORICL (Observe, Reflect, Improve Children's Learning) tool was co-designed by ECEC experts, service providers and educators to be used for this purpose by educators working with children aged under three years. It is a unique 117-item educator report across five domains of learning and well-being that rates the experiences of individual children, and the responses of educators and peers to the child's initiatives, actions and communications. This paper describes the first feasibility study of ORICL in 12 ECEC services across Australia with a focus on the quantitative child data collected, and early psychometric properties of the tool. ORICL records were provided by 21 educators for a total of 66 children. Findings suggest that the ORICL items can be readily observed and rated by educators for children aged under three years, the rating scale is appropriate, and there is early evidence to support the domain structure of the tool. Further research on the ways such a tool can provide useful data for both educators and researchers, and stimulate enhanced practice in infant-toddler ECEC, is warranted.
\end{abstract}

Keywords: infant-toddler, early childhood education and care, observation guide, educators, tool, reflective practice

\section{Introduction}

In 2013, the World Health Organization (WHO) made a strong case for global investment in very early child development: "the first 3 years of a child's life are the time when a child has the greatest plasticity for growth and development, even under adverse circumstances" (Chan, 2013: page nos 1515). In many developed nations, an important context for this investment is early childhood education and care (ECEC). Across OECD countries, on average $34 \%$ of 1 -year old children, and $46 \%$ of 2 -year-old children were enrolled in ECEC in 2018 (OECD, 2020). Ensuring that children are exposed to the highest quality of experiences in these services is critical for optimal child development. However, it is common that educators report receiving insufficient training on the developmental and pedagogical needs of children under 3-years (Chu, 2016).

A cornerstone of high-quality practice is the ability of educators to observe and reflect on children's experiences to extend their learning (ACECQA, 2016; Melvin et al., 2019), yet few tools exist to support educators to do this. While multiple approaches to measuring and enhancing ECEC quality for children aged under 3-years have been developed and implemented, none of these tools aim to build capability in educators of all qualification levels to observe and reflect on the experiences of individual young children in their care (MeMoQ, 2015). This paper documents the first study of a new and innovative tool, ORICL (Observe, Reflect, Improve Children's Learning), co-designed with the field, for the field (BLINDED, Submitted). ORICL is a 117-item educator-report tool that aims to gauge and improve ECEC quality through a focus on educator observations of individual children aged 
under 3-years. This study aimed to establish the feasibility of ORICL to be implemented in centre-based and home-based ECEC, using Australia as a case study.

\section{Early childhood education and care for children aged under 3-years.}

In Australia, 24\% of 1-year-old children, and 37\% of 2-year-old children attend ECEC services (ABS, 2017). Growing evidence shows the important role these early learning experiences have for longer term developmental outcomes (Hotz and Wiswall, 2019). The strongest evidence for universal ECEC services, comes from several robust quasiexperimental studies in Europe that link early centre-based care with enhanced motor and language development (Blau, 2021). Population data from Australia also suggest greater exposure to centre-based care prior to 3 -years is associated with cognitive skill increases at age 7, but also poorer behavioural and social functioning (Coley et al., 2015), echoing findings in the United States (Coley et al., 2013). No doubt, the conferral of ECEC benefits will rely on a complex interaction among attendance, dosage, child characteristics, and the quality of ECEC experienced (Gilley et al., 2015). Quality is in part related to educator qualification and skill (Schaack et al., 2017), which varies among and within countries (Oberhuemer and Schreyer, 2018). For example, in much of Europe, infant and toddler educators are required to hold a 4-year bachelor degree (Blau, 2021), whereas in Australia and many US states, a vocational certificate is sufficient (Macfarlane and Lewis, 2012).

Australia, in recognition of disparities in qualifications and quality across state jurisdictions, introduced a national system of quality assurance for all ECEC services which includes National Quality Standards (NQS). Although this has resulted in steady improvements in quality since its introduction, currently 13\% of Australia's 8,035 centrebased ECEC services and $41 \%$ of 507 home-based ECEC schemes do not meet the standards (ACECQA, 2020). Under-performance on the NQS is most evident in Quality Area One (QA1) "Educational program and practice", with $13 \%$ of services rated as not meeting this standard (ACECQA, 2020). Within QA1, the indicator that services find the most challenging to meet is Assessment and Planning, requiring educators "to take a planned and reflective approach to implementing the program for each child", specifically to ensure that "each child's learning and development is assessed or evaluated as part of an ongoing cycle of observation, analysing learning, documentation, planning, implementation, and reflection" (ACECQA, nd, QA1 element 1.3.2).

\section{Achieving quality for infant-toddler ECEC programs}

The extent to which ECEC provisions are universally of high quality is a key concern of Australian and international governments and regulators (EACEA, 2019; OECD, 2017). However, the empirical evidence for the role of ECEC quality in terms of children's outcomes has been somewhat mixed. While some research finds that duration and dosage of ECEC exposure is more highly predictive of child outcomes than quality measures (Coley et al., 2013), others have linked higher quality to enhanced learning trajectories for children when compared to children experiencing low quality care (Ruzek et al., 2014), and particularly for socio-economically disadvantaged children (Van Huizen and Plantenga, 2015). Noteworthy here are criticisms of the way that quality is measured in ECEC (Sabol et al., 2013). Despite this and regardless of nuances in the evidence for the role of quality in child outcomes, any systematic efforts to enhance the quality that children experience must be welcomed, given increasing participation rates in ECEC by the youngest children. 
Indeed, it is possible that the experience of poorer quality ECEC by many children, particularly before age 3, is at least partially responsible for poor outcomes at school age (Shuey and Kankaraš, 2018). In Australia, for example, despite decades of significant government investment and a focus on access in the preschool sector (Hurley et al., 2020), there has been continuing or even increasing rates of developmental vulnerability for children at school entry (Australian Government Department of Education and Training, 2019). The mechanisms of this relationship are difficult to pinpoint, as they can be a result of several factors that act to compound disadvantage for very young children. ECEC settings for children aged under 3-years generally have educators with lower qualifications (Macfarlane and Lewis, 2012) than those for children aged 3-5 years. Further, infants and toddlers are more likely to attend home-based, rather than centre-based ECEC, in which poor quality is more common (Ruzek et al., 2014) and, importantly, children from socio-economically disadvantaged households are more likely to attend poorer quality care (Ruzek et al., 2014).

Taken together, it is clear (1) there is a need for improvement in quality of infanttoddler ECEC, particularly in relation to assessment and planning, and (2) improvement has the potential to enhance outcomes for the increasing number of young children participating. We argue the best way to enhance quality is to provide educators with tools to improve their understanding of children aged under 3-years and the skills they need to support children's learning, development, and wellbeing. Existing approaches to measuring and enhancing ECEC quality are not designed to be used by all educators (regardless of qualification level) or to build capability in skills of observation, reflection, interpretation, documentation and planning. Nor are they designed to focus attention, and comprehensively report, on learning experiences of an individual child, despite wide recognition that child-centred pedagogy is essential to high quality ECEC (Melvin et al., 2019: page nos 155).

\section{The current study}

In this paper we document our effort to fill the gaps described above and report on quantitative findings of the first study of a new tool, ORICL (Observe, Reflect, Improve Children's Learning), developed to support and enhance educator practice and therefore children's learning. ORICL's relevance and potential is underlined by the fact it was codesigned collaboratively with the field, for the field (see BLINDED et al., 2021), as a tool to both gauge and improve ECEC quality for children aged under 3-years.

\section{The Observe, Reflect, Improve Children's Learning (ORICL) Tool: a unique new tool.}

The ORICL tool was created to fill a significant gap in ECEC educator capabilities, with four key points of innovation. First, the ORICL focusses specifically on children in the first three years of life, an age group that is under-emphasised in early childhood educator training compared to children aged 3-years and over (Chu, 2016). This age group is seen by educators as more difficult to plan for, and/or 'find' in national early years curriculum frameworks (Davis and Dunn, 2019). Second, the ORICL focusses on observations of young children's experiences within the natural ecology of ECEC, rather than context-generic observations focussed on children's developmental competency in specific areas as other tools do (e.g., Ages and Stages Questionnaire: Bricker and Squires, 1999). ORICL provides a guide for educators to attend to actions and communications of individual children, as well as ways peers and educators respond to children. Used systematically, ORICL can inform planning targeted to each child's interests and pace, as a unique individual learner, and as a participant within a group care setting. Third, ORICL focusses on the 
quality of individual children's experiences in ECEC rather than overall quality of the ECEC environment at room or centre level. Existing tools, (e.g. Australia-wide National Quality Standard Assessment and Rating (NQS A\&R) process, ACECQA, 2012; CLASS-Infant, Jamison et al., 2014), provide ratings at room level and are based on all educators and children present. This approach assumes 1) quality in a room affects all children equally, and 2) quality is a property of a room, rather than the individual, dialectic relationship between a child and caregiver. The approach taken in ORICL recognises that each child experiences and responds to the ECEC environment in their own way, and in turn educators respond differently to individual children. This is aligned with current (and foundational) thinking about individualised pedagogy in ECEC (Melvin et al., 2019). Fourth, the ORICL is designed to be completed by educators of all qualification levels, even those with a minimal level of pre-service training, and does not require certification to use the tool itself unlike existing tools that often require extensive training and are typically implemented by visiting specialists (e.g., CLASS-Infant; NQS A\&R). This means the ORICL has higher potential to be scaled up for wide use, including rural and remote areas, and builds capability in educators themselves to engage in observations that tap into ECEC quality, rather than positioning others as experts.

\section{The domain structure of ORICL}

Co-designed with educators, the domain structure of the ORICL is aligned with the five learning outcomes identified in Australia's Early Years Learning Framework (EYLF) (DEEWR, 2009). The EYLF is mandated for all ECEC services under NQS Quality Area 1, and its implementation is assessed under the NQS A\&R process (Tayler, 2018). The EYLF was written for all children from birth to 5-years and does not specify learning outcomes by child's age. The EYLF provides guidance for educators in the form of example statements for each learning outcome about how educators can promote learning. For example, "children celebrate and share their achievements with others" is an example evidencing Learning Outcome 1: Children have a strong sense of identity, and "educators ensure all children experience pride and confidence in their achievements" is an example of how this learning outcome can be promoted (DEEWR, 2019: page nos 23).

Although aligned with the EYLF, the purpose of the ORICL tool for educators is not to assess the child in relation to the EYLF outcomes, but to capture a more rounded understanding of the child's whole experience in the setting. ORICL items within each domain focus not only on target children, but also on educator responses and peer responses to target children. In this way, the tool is designed to stimulate enhanced educator observation and reflection, beyond child's performance of particular behaviours. For example, Item 2 in ORICL Domain 1, Identity, Belonging, Sense of Self, Family and Culture, asks the educator to consider the extent to which, "When this child is exploring his/her cultural identity, educators notice and respond in ways that acknowledge and respect this child's family and culture, and provide the child with experiences and materials that assist them to learn about their community, reflect the child's cultural heritage and culturally valued ways of learning." Examples of experiences and materials educators could provide are also listed: "e.g., using language; displaying artwork;" Observing and rating this item prompts the educator to look for specific observable behaviours (child and educator), consider whether resources are provided for the child, and use this information to plan for experiences that will encourage the child's sense of identity. 
The ORICL items, 117 in total, were designed to capture three aspects of an individual child's experiences: the child's demonstration of actions, communications and responses to materials and others' invitations; other children's (peers) responses to the child's actions and communications; and educators' responses to the child's actions and communications. Table 1 provides domain titles, number of items in each domain, and example items. For each item, examples are provided to clarify and illustrate the focus of the observation and encourage educator reflection.

Table 1 ORICL domains, items and examples to focus educators' observations for each domain.

\begin{tabular}{|c|c|c|c|}
\hline ORICL Domain & $\begin{array}{l}\text { Number of } \\
\text { items in } \\
\text { domain }\end{array}$ & $\begin{array}{l}\text { Item number, content } \\
\text { (bold) and focus } \\
\text { (underlined) of } \\
\text { observation }\end{array}$ & $\begin{array}{l}\text { Behavioral examples of } \\
\text { the focus of observation, } \\
\text { provided as a guide for } \\
\text { educators }\end{array}$ \\
\hline $\begin{array}{l}\text { 1. Identity, } \\
\text { belonging, } \\
\text { sense of self, } \\
\text { family and } \\
\text { culture }\end{array}$ & 23 & $\begin{array}{l}\text { IDO4 This child } \\
\text { identifies and } \\
\text { demonstrates their } \\
\text { preference for, and } \\
\text { knowledge of, } \\
\text { familiar people }\end{array}$ & $\begin{array}{l}\text { Looking at, reaching up, } \\
\text { moving closer, pointing, } \\
\text { gazing or pointing to } \\
\text { familiar faced (including } \\
\text { photos); or identifying } \\
\text { their own family members } \\
\text { in a group of family } \\
\text { members; or seek out } \\
\text { and/or naming familiar } \\
\text { peers and educators }\end{array}$ \\
\hline $\begin{array}{l}\text { 2. Connectedness } \\
\text { with others }\end{array}$ & 16 & $\begin{array}{l}\text { CON02 When another } \\
\text { child or group of } \\
\text { children is near this } \\
\text { child or engaged in } \\
\text { something this child } \\
\text { notices, this child } \\
\text { shows interest in the } \\
\text { other children. }\end{array}$ & $\begin{array}{l}\text { Looks, watches, } \\
\text { approaches, follows, } \\
\text { imitates, joins in }\end{array}$ \\
\hline $\begin{array}{l}\text { 3a. Emotional } \\
\text { wellbeing }\end{array}$ & 18 & $\begin{array}{l}\text { EM12 When this child } \\
\text { is upset, educators } \\
\text { have ways to soothe } \\
\text { the child that match } \\
\text { with this child's } \\
\text { preferences. }\end{array}$ & $\begin{array}{l}\text { Talking, singing, physical } \\
\text { support, distraction, } \\
\text { providing a preferred } \\
\text { soothing item }\end{array}$ \\
\hline $\begin{array}{l}\text { 3b. Physical } \\
\text { wellbeing }\end{array}$ & 25 & $\begin{array}{l}\text { PH01 When materials } \\
\text { are available for active } \\
\text { physical play, this } \\
\text { child engages in } \\
\text { active whole-body } \\
\text { movement. }\end{array}$ & $\begin{array}{l}\text { Crawls, rolls, walks, runs, } \\
\text { chases, falls or throws self } \\
\text { onto cushions, climbs on } \\
\text { or into things and } \\
\text { equipment, jumps on } \\
\text { things and equipment, } \\
\text { rolls over, kicks while } \\
\text { walking or running }\end{array}$ \\
\hline
\end{tabular}




\begin{tabular}{|c|c|c|c|}
\hline ORICL Domain & $\begin{array}{l}\text { Number of } \\
\text { items in } \\
\text { domain }\end{array}$ & $\begin{array}{l}\text { Item number, content } \\
\text { (bold) and focus } \\
\text { (underlined) of } \\
\text { observation }\end{array}$ & $\begin{array}{l}\text { Behavioral examples of } \\
\text { the focus of observation, } \\
\text { provided as a guide for } \\
\text { educators }\end{array}$ \\
\hline $\begin{array}{l}\text { 4. Constructing } \\
\text { knowledge }\end{array}$ & 18 & $\begin{array}{l}\text { CK03 This child's } \\
\text { efforts to engage with } \\
\text { their environment } \\
\text { (materials, activities, } \\
\text { educators, and peers) } \\
\text { show curiosity }\end{array}$ & $\begin{array}{l}\text { Being open to trying new } \\
\text { things; displays verbal } \\
\text { and non-verbal inquisitive } \\
\text { behaviors such as } \\
\text { reaching and grasping, } \\
\text { mouthing, gesturing } \\
\text { towards new objects, } \\
\text { peers, others }\end{array}$ \\
\hline 5. Communication & 16 & $\begin{array}{l}\text { CO03 When this child } \\
\text { initiates } \\
\text { communication with } \\
\text { other children, this } \\
\text { child's peers listen } \\
\text { and respond by } \\
\text { communicating with } \\
\text { this child }\end{array}$ & $\begin{array}{l}\text { Child looks into child's } \\
\text { eyes; points or gestures; } \\
\text { vocalizes, babbles, talks, } \\
\text { uses signs; moves closer } \\
\text { or reaches; shows object; } \\
\text { directs expression of } \\
\text { emotion }\end{array}$ \\
\hline
\end{tabular}

\section{Instructions for using ORICL.}

ORICL has been designed for use by educators during their regular work. Item ratings should capture what life is like for the child on a typical day in their ECEC setting.

Completing the tool does not require educators to do anything different from what is typically provided in their usual program. While each item includes examples of child, peer, or educator behaviours, these are only suggestions, included as observational triggers; for example, seeing a child perform one of the examples given or a similar one is sufficient for an educator to rate the item. Rating options for each item are on a six-point scale, with an option for "no opportunity to observe" (see Table 2). Educators are asked to read and consider each item and use these to observe an individual child over a period of days or weeks, depending on the child's attendance pattern. Educators select the most appropriate response and have the option to add comments.

Table 2 The ORICL response options

\begin{tabular}{|c|c|}
\hline No Opportunity & $\begin{array}{l}\text { No opportunity to see this action or response during the } \\
\text { observation period. }\end{array}$ \\
\hline Not Yet [scored as zero] & $\begin{array}{l}\text { This child, child's peers, or educator has not yet } \\
\text { demonstrated this action or response. }\end{array}$ \\
\hline 1-Rarely & $\begin{array}{l}\text { The action or response occurs rarely as part of this child's } \\
\text { experience }\end{array}$ \\
\hline 3-Sometimes & $\begin{array}{l}\text { The action or response occurs enough to be somewhat } \\
\text { characteristic of this child's experience }\end{array}$ \\
\hline 5-Always & $\begin{array}{l}\text { The action or response occurs consistently and is } \\
\text { characteristic of this child's experience }\end{array}$ \\
\hline
\end{tabular}




\section{Research questions}

This feasibility study is part of a larger, overarching project that developed and piloted the ORICL. It is the first use of ORICL by educators in the field and analysis focusses on child data provided by educators on ORICL and what this tells us about how educators used the tool, and psychometric properties of ORICL. The study aimed to explore:

1. To what extent were educators able to make observations for each of the ORICL items?

2. To what extent did educators use the full range of responses available on each item?

3. How do the items within each domain perform and relate to each other?

4. How are the ORICL subsets of items that focus on the child, educator responses to the child, and peer responses used?

\section{Method}

\section{Study design}

We used a cross-sectional clustered design. ORICL data were collected about children from educators, who in turn were clustered into individual ECEC services. These services were recruited through ECEC organisations that participated in the co-design of the ORICL tool (see BLINDED et al., 2021) and through researchers' professional networks. Services recruited catered for children aged from 6-weeks to 5-years: centre-based long day care (LDC) and home-based family day care (FDC). In Australia, LDC and FDC are licenced services that participate in the NQS Assessment \& Rating process, and provide an approved educational program aligned with the EYLF. FDC educators provide care in their own home for up to four children under the age of 5-years, including their own children, and are supported by the coordination unit of the FDC scheme where staff must hold at least a 2-year Diploma level education and care. Licenced LDC centres vary in numbers and ages of children they enrol but must adhere to ratios of 1 educator per 4 children for children under 24-months, and 1 educator per 5 children aged 25- to 36-months. In LDC, educators must hold at least a 6-month Certificate III ECEC qualification and at least $50 \%$ of educators hold a Diploma qualification. LDC services caring for children over 3-years must also employ a Degree qualified early childhood teacher.

\section{Participants}

\section{Early childhood services}

Recruitment took place in five states and territories within Australia. For LDC, three research members approached head office of overarching service organisations where an existing professional relationship was established. Managers who had a broad view across the organisation then recommended possible research sites, based on centre-level interest in birth to three research, and introduced the researcher to centre Directors. In addition, a research team member with an existing professional relationship with a stand-alone service made a direct approach to the centre Director. Once the research team had provided full information to Directors and gained their consent, Directors then invited eligible educators at the service (those working with children aged 6 weeks to 36 months) to consent to the research. For FDC, a research team member with an existing professional relationship approached each FDC scheme coordination unit, which in turn approached individual FDC educators on behalf of the research team. 
A total of 12 different services agreed to participate. Five were FDC services, in New South Wales (NSW) and Victoria (VIC), and seven were LDC centres (two in NSW, two in Queensland (QLD), three in West Australia (WA). Eight services were in major cities, two in inner regional areas (both FDC) and two in outer regional areas (both LDC). Three services were in postcodes ranked in the lowest four deciles of socio-economic advantage (one was an LDC, two were FDC services), with the remaining eight services in postcodes ranked in the top five deciles of socio-economic advantage (Australian Bureau of Statistics, 2016).

\section{Educators}

A total of 21 educators participated in the study. At each of the five FDC settings, one educator was recruited. Educator recruitment numbers at the LDC centres were as follows: two and five educators at each of the NSW centres, one and four educators at each of the QLD centres, one educator at each of two WA centres, and two educators at the third WA centre. A total of 20 educators identified as female and one identified as indeterminate/intersex/unspecified. Educators were aged 35-39 years (33\%), 25-29 years $(19 \%), 40-44$ years (14\%). The youngest age bracket was $20-21$ years (one educator), and the oldest was 55-59 years (two educators). One identified as Aboriginal and/or Torres Strait Islander, and eight (38\%) spoke a language other than English at home including Portuguese, Bangla, Burmese, Gujarati, Mandarin, Punjabi, and Swahili. Six educators used a language other than English at their workplace including French, Portuguese, Hindi, and Bangla. All educators had worked in the profession for at least 3 years with most for 6-10 years (38\%), $11-15$ years $(19 \%)$, or more than 20 years $(19 \%)$. The most common level of education was 2-year Diploma (71\%), followed by Certificate (14\%). One educator had a Bachelor degree, one an advanced Diploma (more than 2-years study), and one was studying for her Diploma. Most educators were employed full time (76\%) with five (24\%) employed part-time.

Educators had been employed at their current workplace for 6-10 years $(33 \%)$, less than one year $(24 \%), 1-2$ years $(19 \%), 3-5$ years $(14 \%)$ or for 11 or more years $(10 \%)$. On average, most educators worked with 10-20 different children per week (38\% of educators) or 21-30 children per week (24\%). Of the remaining eight educators, two worked with less than five different children per week, three worked with five to nine different children per week, and three worked with more than 30 different children each week.

\section{Children}

Eligible families for recruitment at each service were those with a child aged between 6-weeks and 36-months. Directors at LDCs and educators at FDCs, invited all eligible families to consent to the research. This resulted in 66 children participating in the research, most children $(n=57)$ attended the seven LDC centres, and nine children attended the five FDC homes. ORICL data were provided by each educator in the study for between one to seven children. Educators working in LDC tended to complete the ORICL for more children than educators working in family day care (average number of children per LDC educator $=$ 3.6; per FDC educator $=1.8$ ).

The 66 children $(58 \%$ girls, $\mathrm{n}=38)$ ranged in age from 7- to 33 -months, with a mean age of 20.7 months ( $\mathrm{SD}=7.2)$. There were 10 children aged $<12$ months $(16 \%) ; 33$ children aged between 13- and 24-months (52\%), and 23 children aged 25- to 33-months (32\%). Three children spoke a language other than English (Chinese, Greek, French) and there were no Aboriginal or Torres Strait Islander children in the sample. Four children were described as having a disability or developmental delay with descriptions including 'hip', physical, 
sensory and anxiety concern, late walking, and right eye palsy. Children attended their ECEC service for one to five days a week with the modal days per week being three. Hours attended across the week ranged from 8 to 50 with a mean of 30.30 hours $(\mathrm{SD}=12.03)$.

\section{Procedure}

Educators completed a short survey about their work, training and experience in ECEC, read the ORICL instructions and completed a paper copy of the ORICL for each child in the study over a four-week period. A research assistant sent/called the educators with reminders after two weeks. Completed forms were checked for completeness and entered into an Excel database, then exported to SPSS for analyses. While the focus in this paper is the data provided across the sample for children, educators also provided data on their experiences with the tool including how long it took to complete and the benefits and challenges of its use (see BLINDED, 2021, for full reporting of this data).

\section{Analysis}

First, the distribution of missing values ("not observed") was examined for each item and domain (RQ 1), along with a set of descriptive analyses for all ORICL items (RQ 2). The Cohen's alpha for each domain was estimated to establish internal reliability and domain summary scores (an average of all items within each domain) and bivariate correlations among them, and children's age and sex were examined (RQ 3). Finally, we produced Cronbach's alphas for the substructure of ORICL that groups together items related to the child, peers, and educator behaviours (RQ 4). All analyses were conducted using SPSS Version 26.

\section{Results}

\section{To what extent were the educators able to observe and rate ORICL items?}

Descriptive statistics for each of the ORICL items are in Appendix 1. The educators' ability to provide ratings on ORICL items is summarized in Table 3 . Out of a possible 7,722 item responses (117 items times 66 children), only 38 were marked as "not observed" $(0.5 \%)$ suggesting high face validity of the items. For 109 of 117 ORICL items, educators generally used a score from the scale provided (0-5), with two or fewer educators marking "not observed". For the remaining eight items, educators used the 'not observed' response for three or more children (see Table 3). Of note, Item 9 in the Emotional Wellbeing domain (When this child shows emotions, the emotional expression does not seem to match the circumstances) had many uses of 'not observed' $(\mathrm{n}=20)$ and upon reflection, this item was the only negatively, or reverse worded item in the ORICL which may have caused confusion. In the analyses that follow, this item is excluded. We examined through cross-tabulation of descriptive statistics whether there was any suggestion in the data that specific educators were more likely to use 'not observed', or whether 'not observed' was used more often for particular ages of children (e.g., younger vs older), with no evidence this was the case. 


\section{Table 3}

Items in which 'not observed' was used for three or more children across the sample.

\begin{tabular}{|c|c|c|c|}
\hline Domain & $\begin{array}{l}\text { Item } \\
\text { number }\end{array}$ & Item & $\begin{array}{l}\text { N for use } \\
\text { of 'not } \\
\text { observed' }\end{array}$ \\
\hline Identity & 22 & $\begin{array}{l}\text { This child explores his/her cultural identity and learns about the social } \\
\text { world by engaging in cultural activities. }\end{array}$ & 4 \\
\hline \multirow[t]{2}{*}{ Connectedness } & 04 & When another child is crying, this child shows concern & 3 \\
\hline & 05 & When another child is crying, this child shows empathy & 3 \\
\hline \multirow[t]{2}{*}{ Emotional wellbeing } & 09 & $\begin{array}{l}\text { When this child shows emotions, the emotional expression does not seem } \\
\text { to match the circumstances }\end{array}$ & 19 \\
\hline & 10 & $\begin{array}{l}\text { When this child is in their usual group, the child's peers seem to read the } \\
\text { emotional cues of the child well and respond with an attempt at support }\end{array}$ & 3 \\
\hline Physical wellbeing & 20 & $\begin{array}{l}\text { When rest or sleep is offered, this child has some self-soothing strategies to } \\
\text { use }\end{array}$ & 6 \\
\hline Constructing knowledge & 16 & $\begin{array}{l}\text { When this child engages with their environment (materials, activities, } \\
\text { educators, and peers), this child remembers connections between cause and } \\
\text { effect and transfers those connections to a new situation }\end{array}$ & 3 \\
\hline Communication & 16 & $\begin{array}{l}\text { When this child engages with text-based play or experiences, educators } \\
\text { notice and respond in ways that acknowledge and encourage this child's } \\
\text { efforts and ideas }\end{array}$ & 3 \\
\hline
\end{tabular}


To what extent did educators use the full range of responses available on each item?

Item-level statistics (mean, median, range, min, max; Table 4) and frequency tables (see Appendix 1) were examined to understand the extent to which educators tended to use the whole range of responses available for each item. Only two items had a range of one, with all educators using either 'most of the time' or 'always' (4-5 on the scale) as their responses: Identity domain Item 24: Educators respect and build on this child's family's child-rearing practices; Physical wellbeing Item 25: If parents share information about sleep preferences for children (timing, duration etc), educators use this information to adjust rest and sleep routines and actions to align with parent and child sleep preferences. Interestingly, both items related to educator responses and were positively skewed. This trend for highly positively skewed responses was not found in the remaining 41 educator-focussed items across ORICL.

\section{How do the items within each domain perform and relate to each other?}

Internal reliability within each of the ORICL domains was high (Table 4). Scores within each domain were totalled and averaged and bivariate correlations among the domain totals and child age and gender examined (Table 4$)$. There were strong correlations $(>.70)$ among the domains and moderate correlations among domain scores and child age in months (.42 to .66). The strongest correlations with age were the domain scores for Constructing knowledge, and Communication.

Table 4

Correlations among summed domain scores, child age and gender

\begin{tabular}{llllllll}
\hline & 1 & 2 & 3 & 4 & 5 & 6 & 7 \\
\hline 1. Identity & 1 & & & & & & \\
2. Connectedness & $.80^{*}$ & 1 & & & & & \\
3. Emotional & $.76^{*}$ & $.79^{*}$ & 1 & & & & \\
wellbeing & & & & & & & \\
4. Physical wellbeing & $.74^{*}$ & $.74^{*}$ & $.72^{*}$ & 1 & & & \\
5. Constructing & $.86^{*}$ & $.81^{*}$ & $.82^{*}$ & $.83^{*}$ & 1 & & \\
knowledge & & & & & & & \\
6. Communication & $.76^{*}$ & $.85^{*}$ & $.67^{*}$ & $.67^{*}$ & $.80^{*}$ & 1 & \\
7. Child age & $.53^{*}$ & $.53^{*}$ & $.42^{*}$ & $.46^{*}$ & $.66^{*}$ & $.63 *$ & 1 \\
8. Child gender & .11 & .07 & .04 & -.00 & .00 & .03 & .02 \\
(female) & & & & & & & \\
\hline Range & $2.25-$ & $1.94-$ & $2.83-$ & $2.68-$ & $2.19-$ & $.56-$ & $7-33$ \\
& 4.83 & 4.75 & 4.89 & 4.83 & 5.63 & 4.88 & \\
Mean & 3.95 & 3.69 & 3.78 & 4.08 & 4.13 & 3.65 & 20.73 \\
SD & .60 & .66 & .48 & .41 & .81 & .92 & 7.21 \\
$\quad$ Alpha & .91 & .87 & .80 & .88 & .91 & .93 & NA \\
\hline
\end{tabular}

How are the ORICL subsets of items that focus on the child, educator responses to the child, and peer responses used?

The ORICL also has a potential sub-structure related to whether items are focussed on the child's observed behaviors, other children's (peers) responses to the child, or educators' 
responses to the child. Table 5 displays numbers of items in total, as well as in each learning domain that correspond with this child, peer, or educator-related focus, along with the internal reliability estimate for these groupings of items. For those groupings where alphas were below 0.7 (namely educator items for the Identity, Connectedness, and Emotional Wellbeing domains), we examined whether dropping certain items would improve this estimate of internal reliability on this dimension. No items could be identified, with inclusion of all domain items producing the best alpha.

\section{Table 5}

ORICL item groups related to child, peers, and educator responses.

\begin{tabular}{lllll}
\hline Learning domain & $\begin{array}{l}\text { Child-related } \\
\text { items }\end{array}$ & $\begin{array}{l}\text { Peer-related } \\
\text { items }\end{array}$ & $\begin{array}{l}\text { Educator-related } \\
\text { items }\end{array}$ & Total \\
\hline Total in ORICL & $63(.97)$ & n (Cronbach's alpha) & \\
Identity & $10(.86)$ & $5(.87)$ & $43(.93)$ & 116 \\
Connectedness & $10(.87)$ & 2 & $8(.63)$ & 23 \\
Emotional wellbeing & $10(.70)$ & 1 & $4(.63)$ & 16 \\
Physical wellbeing & $13(.83)$ & 0 & $7(.61)$ & 18 \\
Constructing & $12(.93)$ & 0 & $12(.86)$ & 18 \\
knowledge & & & $6(.75)$ & 16 \\
Communication & $8(.88)$ & 2 & $6(.84)$ & \\
\hline
\end{tabular}

\section{Discussion}

This paper has presented findings of the first feasibility study of a new tool designed specifically for educators of infants and toddlers, ORICL. Overall, the findings are promising and demonstrate the feasibility of ORICL for the field, and for future research programs. The 117 items of the ORICL were able to be completed by educators, regardless of their prior education level, for children under 3-years. The response scale appeared appropriate with data showing usage right across the scale. The structure of the tool, designed to align with domains of the national early childhood curriculum, was supported by the data with strong internal reliability estimates, and cross-domain correlations as would be expected. However, further larger sample data is required to undertake specific exploratory and confirmatory factor analyses to further confirm this structure.

The ORICL presents several contributions and addresses important existing gaps in infant and toddler education research and practice. First, the tool was designed with the field, for the field. Using educators' own observations and experience directly, rather than relying on external observers, has been the cornerstone of ORICL philosophy and the codevelopment process (BLINDED et al., 2021). It is likely that the high relevance of ORICL items, as evidenced by completion rates, reflects the extensive input of educators in the development of these items. Second, ORICL was designed to measure contextual ECEC quality at the individual child level, rather than the group level. This is achieved through focussing not only on individual children and their observable behaviours, but also the responses of peers and educators within that context. Findings here suggest educators were equally able to use items focussed on peers and educators, as they were able to observe the target child themself. Third, unlike other existing tools, ORICL was designed to be used by staff of various qualification levels, not just by trained assessors. The sample of educators in 
this study had a range of education levels as well as cultural and language backgrounds, working in a range of sociodemographic regions, and all were able to complete ORICL.

In view of existing gaps in the professional development available for educators of the youngest children. Our results are very promising, suggesting that the ORICL tool may be useful in supporting educators to observe, reflect and report on children's interactions within the early education setting. A recent study by Romo-Escudero et al. (2021) measured observational ability of toddler educators in centre-based childcare by having them note their observations of pre-recorded videos of classroom activity. A key finding was that the ability of educators to notice markers of toddler social-emotional development, and effective educator-child interactions was overall limited. However, educators were not provided with prompts of what to look for, and thus the task differed substantially from ORICL observations which are scaffolded with concrete examples and undertaken in naturalistic settings. Importantly, there was some evidence that educators' abilities to notice effective educator-child interactions in the pre-recorded videos was associated with more effective educator observed in the classroom (Romo-Escudero et al., 2021). This provides some support to our argument that should the ORICL support educators' capacity to observe and reflect on children's learning, it may also improve practice.

Prior to further research, one ORICL item will be changed given the data presented here. Item 9 in the Emotional Wellbeing domain had many uses of 'not observed' $(n=20)$ with the negative wording of the item making it difficult for educators to score. In the next ORICL iteration this item will read "when this child shows emotions, the emotional expression tends to match the circumstances." No other findings suggested specific changes are needed to the ORICL before further study is conducted.

\section{Limitations}

Taken together, the findings presented here suggest the early feasibility of ORICL, but further research is required, and this small study is not without limitations. Specifically, a much larger sample size is required to a) fully confirm the internal reliability of the ORICL, b) understand any shared variance as a function of clustering of children within educators, and educators within centres, c) consider whether educators of different qualification levels, or in different setting types or geographic areas show systematic differences in their use of ORICL, d) understand whether there are child age-effects in the way ORICL is used.

\section{Future implications}

ORICL was designed as a data collection tool, and as an intervention to enhance educator practice, and ultimately the quality of experiences in ECEC for young children. While this small study is not able to provide evidence for any of these anticipated positive outcomes, the educator feedback (qualitative and quantitative) strongly suggests that the potential for such effectiveness in terms of enhancing educator practice is high (BLINDED, 2021). We argue that through guiding educators to observe how and what young children are learning, and enhancing their capacity to reflect on this, ORICL, has the potential to lead to enhanced educator practice, individually targeted educational programs and enhanced child outcomes. Given continuing rates of developmental vulnerability at school entry (Australian Government Department of Education and Training, 2019) a new approach to promoting quality in early childhood education services is needed. Future ORICL studies should involve 
a longitudinal, experimental design, including measures of educator practice and child outcomes over time, to establish evidence for effectiveness.

\section{Conclusion}

The findings presented here demonstrate the feasibility and relevance of ORICL and suggest high potential for its use in the infant and toddler early childhood education and care sector. Further research on ORICL psychometric properties as well as implementation and evaluation of the extent to which its use stimulated the desired enhancements to educator practice is warranted. Despite our study's limitations, it firmly establishes ORICL as an innovative tool for the early childhood care and education field. The ongoing testing and wider use of the ORICL will assist services and educators to understand and evaluate the enablers and barriers to learning for each child in their setting and modify these as needed to enhance the care and education provided for each child. Ultimately, higher quality education and care for our youngest citizens is likely to have far-reaching benefits.

\section{References}

Australian Bureau of Statistics (2016) Census of population and housing: Socio-economic indexes for areas (SEIFA). Available at:

https://www.abs.gov.au/ausstats/abs@.nsf/Lookup/by\%20Subject/2033.0.55.001 201 6 Main\%20Features SEIFA\%20Basics 5 (accessed 1 June 2021)

Australian Bureau of Statistics (2017) Childhood education and care. Available at: https:/www.abs.gov.au/statistics/people/education/childhood-education-and-careaustralia/latest-release (accessed 1 June 2021)

Australian Children's Education and Care Quality Authority (ACECQA) (n d) Quality Area 1 - Educational Program and Practice. QA1 element 1.3.2. Available at: https://www.acecqa.gov.au/nqf/national-quality-standard/quality-area-1-educationalprogram-and-practice (accessed 1 June 2021)

Australian Children's Education and Care Quality Authority (ACECQA) (2012) National quality framework for early childhood education and care. Available at: https://www.acecqa.gov.au/national-quality-framework (accessed 1 June 2021)

Australian Children's Education and Care Quality Authority (ACECQA) (2016) Educational program and practice. An analysis of quality area 1 of the national quality standard. Occasional Paper. Available at: https://www.acecqa.gov.au/sites/default/files/acecqa/files/Reports/OccasionalPaper1EducationalProgramandPractice_2.pdf (accessed 1 June 2021)

Australian Children's Education and Care Quality Authority (ACECQA) (2020) National quality framework (NQF) Annual Performance Report, December 2020. Sydney: ACEQCA.

Australian Government Department of Education and Training (2019) Australian early development census national report 2018. Canberra: Department of Education and Training.

Australian Government Department of Education, Employment and Workplace Relations [DEEWR] (2009) Belonging, being and becoming: The early years learning framework for Australia. Available at: https://www.acecqa.gov.au/sites/default/files/2020- 
05/belonging being and becoming the early years learning framework for austra lia.pdf (accessed 1 June 2021)

Blau DM (2021) The effects of universal preschool on child and adult outcomes: Review of recent evidence from Europe with implications for the United States. Early Childhood Education Journal 55: 52-63.

Bricker D and Squires J (1999) Ages and Stages Questionnaires (2nd ed.) Baltimore: Paul H. Brookes.

Chan M (2013) Linking child survival and child development for health, equity and sustainable development. The Lancet 381: 1514-1515.

Chu M (2016) What's missing in most of our early childhood degrees? Focusing more deeply on relationships and learning with infants, toddlers, and their families. Journal of Early Childhood Teacher Education 37(4): 264-281.

Coley RL, Lombardi CM and Sims J (2015) Long-term implications of early education and care programs for Australian children. Journal of Educational Psychology 107(1): 284-299.

Coley RL, Votruba-Drzal E, Miller PL et al. (2013) Timing, extent, and type of childcare and children's behavioral functioning in kindergarten. Developmental Psychology, 49(10), 1859-1873.

Davis B and Dunn R (2019) Professional identity in the infant room. Australasian Journal of Early Childhood 44: 244-256.

Degotardi S (2010) High-quality interactions with infants: relationships with early-childhood practitioners' interpretations and qualification levels in play and routine contexts. International Journal of Early Years Education 18: 27-41.

BLINDED (2021) Implementation and evaluation of ORICL (observing, reflecting, and improving children's learning) tool with infant-toddler educators [Manuscript submitted for publication]. BLINDED

European Commission/EACEA/Eurydice (2019) Key Data on Early Childhood Education and Care in Europe - 2019 Edition. Eurydice Report. Luxembourg: Publications Office of the European Union.

Gilley T, Tayler C, Niklas F et al. (2015) Too late and not enough for some children: early childhood education and care (ECEC) program usage patterns in the years before school in Australia. International Journal of Child Care and Education Policy 9(1): 9.

BLINDED (2021). Co-Design of a New Tool to Support Educators to Observe, Reflect, Improve Learning for Children Birth to Two-Years [Manuscript submitted for publication]. BLINDED

Hotz VJ and Wiswall M (2019) Childcare and childcare policy: Existing policies, their effects, and reforms. The Annals of the American Academy of Political and Social Science 686: 310-338.

Hurley P, Noble KG and Jackson J (2020) Australian investment in education: early childhood education and care. Available at: https://www.vu.edu.au/mitchellinstitute/early-childhood-education/australian-investment-in-education-early-learning (accessed 02 June 2011).

Jamison KR, Cabell SQ, LoCasale-Crouch J et al. (2014) CLASS-Infant: An observational measure for assessing teacher-infant interactions in center-based child care. Early Education and Development 25: 553-572.

Macfarlane K and Lewis P (2012) United we stand: Seeking cohesive action in early childhood education and care. Contemporary Issues in Early Childhood 13: 63-73.

Measuring and Monitoring Quality in Childcare for Babies and Toddlers; MeMoQ (2015). A Pedagogical Framework for Childcare for Babies and Toddlers. Available at: 
https://www.kindengezin.be/img/pedagogische-raamwerk-engelseversie.pdf. (accessed 02 June 2021).

Melvin SA, Landsberg E and Kagan SL (2019) Informed, individualized, and continuous pedagogy. In Kagan SL (ed) The early advantage 2 - Building systems that work for young children. International insights from innovative early childhood systems $\mathrm{New}$ York: Teachers College Press, pp.141-173.

Oberhuemer P and Schreyer I (Eds.) 2018. Early childhood workforce profiles in 30 countries with key contextual data. Available at: www.seepro.eu (accessed 2 June 2021).

Organisation for Economic Cooperation and Development (OECD) (2017) Starting strong 2017: Key OECD indicators on early childhood education and care. Paris: OECD Publishing.

Organisation for Economic Cooperation and Development (OECD) (2020) Education at a Glance 2020: OECD Indicators. Paris: OECD Publishing.

Romo-Escudero F, LoCasale-Crouch J, and Turnbull KLP (2021) Caregiver ability to notice and enact effective interactions in early care classroom settings. Teaching and Teacher Education 97: 103-208.

Ruzek E, Burchinal M, Farkas G et al. (2014) The quality of toddler childcare and cognitive skills at 24 months: Propensity score analysis results from the ECLS-B. Early Childhood Research Quarterly 29(1): 12-21.

Sabol TJ, Soliday Hong SL, Pianta RC et al. (2013) Can rating pre-K programs predict children's learning? Science 341: 845-846.

Schaack DD, Le VN and Setodji CM (2017) Home-based childcare provider education and specialized training: Associations with caregiving quality and toddler socialemotional and cognitive outcomes. Early Education and Development 28(6): 655668.

Shuey E and Kankaraš M (2018) "The Power and Promise of Early Learning”. OECD Education Working Papers. No. 186, Paris: OECD Publishing.

Tayler C (2018) Australia: Maintaining the reform momentum. A case study of the Australian early childhood education and care system. Available at: http://ncee.org/wpcontent/uploads/2019/05/Australia-Case-Study-for-NCEE-052019.pdf (accessed 1 June 2021).

van Huizen T and Plantenga J (2015) "Universal childcare and children's outcomes: A metaanalysis of evidence from natural experiments" Discussion paper Series 15-13, November 2015, Utrecht: Utrecht University. 


\section{Appendix 1 ORICL item descriptive statistics $(n=66)$}

\section{Identity items}

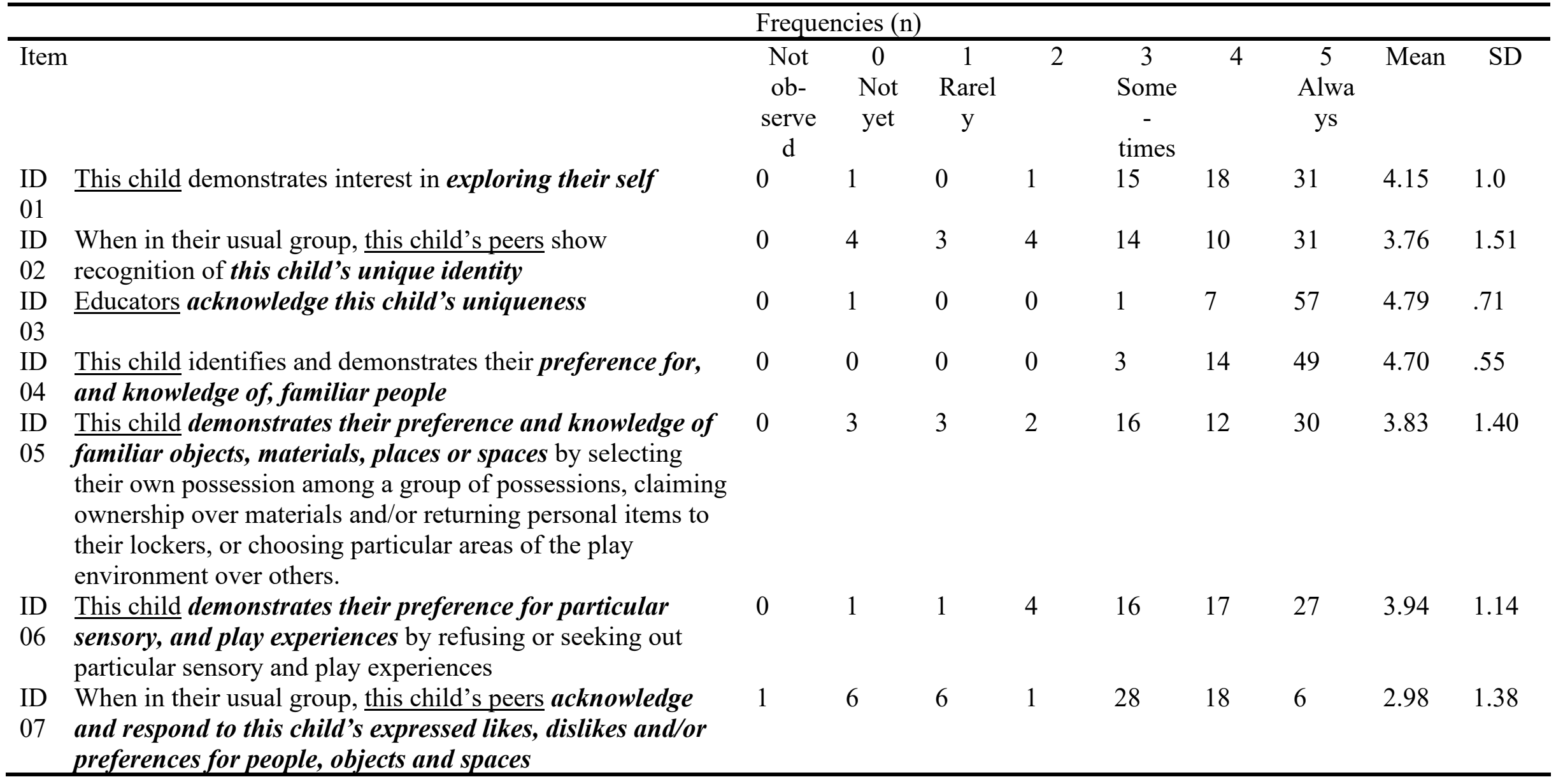




\begin{tabular}{|c|c|c|c|c|c|c|c|c|c|c|}
\hline & & & icies & & & & & & & \\
\hline $\begin{array}{l}\text { ID } \\
08\end{array}$ & $\begin{array}{l}\text { When this child expresses likes, dislikes and/or preferences, } \\
\text { educators acknowledge and respond to the child }\end{array}$ & 0 & 0 & 0 & $\overline{0}$ & 2 & 18 & 46 & 4.67 & .54 \\
\hline $\begin{array}{l}\text { ID } \\
09\end{array}$ & $\begin{array}{l}\text { This child explores and engages confidently with the social } \\
\text { and physical environment }\end{array}$ & 0 & 2 & 1 & 0 & 14 & 19 & 30 & 4.08 & 1.14 \\
\hline $\begin{array}{l}\text { ID } \\
10\end{array}$ & $\begin{array}{l}\text { When this child engages with the social and physical } \\
\text { environment educators allow time, encourage and support } \\
\text { this child's interactions, investigations, persistence and } \\
\text { risk-taking, and express delight in the child's acquisition of } \\
\text { new skills and achievements. }\end{array}$ & 0 & 0 & 0 & 0 & 7 & 27 & 32 & 4.38 & .67 \\
\hline $\begin{array}{l}\text { ID } \\
11\end{array}$ & $\begin{array}{l}\text { This child demonstrates agency and autonomy by choosing } \\
\text { materials and activities; or expressing or asserting opinions } \\
\text { and ideas. }\end{array}$ & 0 & 1 & 1 & 3 & 20 & 20 & 21 & 3.82 & 1.08 \\
\hline $\begin{array}{l}\mathrm{D} \\
12\end{array}$ & $\begin{array}{l}\text { This child demonstrates interdependence by } \\
\text { participating in group decision making; sharing, } \\
\text { cooperating and collaborating with others; listening to, } \\
\text { responding and negotiating with the ideas and rights of } \\
\text { others; or recognising and celebrating the success and } \\
\text { achievements of others. }\end{array}$ & 1 & 12 & 11 & 4 & 22 & 14 & 2 & 2.32 & 1.52 \\
\hline $\begin{array}{l}\text { ID } \\
13\end{array}$ & $\begin{array}{l}\text { When in their usual group, this child's peers listen to and } \\
\text { respect this child's choices, opinions and ideas, cooperate } \\
\text { or collaborate with the child, and/or celebrate the } \\
\text { achievements of the child. }\end{array}$ & 0 & 18 & 3 & 3 & 26 & 15 & 1 & 2.30 & 1.59 \\
\hline $\begin{array}{l}\text { ID } \\
14\end{array}$ & $\begin{array}{l}\text { When this child demonstrates agency and autonomy, } \\
\text { educators respond by listening to and respecting this child's } \\
\text { choices, opinions and ideas. }\end{array}$ & 0 & 2 & 0 & 0 & 1 & 18 & 45 & 4.55 & .95 \\
\hline $\begin{array}{l}\text { ID } \\
15\end{array}$ & $\begin{array}{l}\text { When this child listens to the ideas and opinions, shares, } \\
\text { cooperates or collaborates, and/or celebrates the } \\
\text { achievements of others, educators affirm and support this } \\
\text { action. }\end{array}$ & 0 & 8 & 0 & 0 & 7 & 17 & 34 & 3.92 & 1.61 \\
\hline
\end{tabular}


Frequencies (n)

\begin{tabular}{|c|c|c|c|c|c|c|c|c|c|}
\hline This child's pattern aligns with the rhythm of the day & 0 & 0 & 0 & 3 & 8 & 32 & 23 & 4.14 & .80 \\
\hline $\begin{array}{l}\text { ID When in their usual group, this child's peers engage in } \\
17 \text { similar activities and routines at the same time as the child }\end{array}$ & 0 & 0 & 0 & 4 & 10 & 24 & 28 & 4.15 & .90 \\
\hline $\begin{array}{l}\text { ID Educators ensure routines and transitions for this } \\
18 \text { child are attuned to his/her pattern, are predictable } \\
\text { and clearly communicated or signaled to the child. }\end{array}$ & 0 & 0 & 0 & 0 & 2 & 16 & 48 & 4.70 & .53 \\
\hline $\begin{array}{l}\text { This child is confident in communicating his/her feelings } \\
\text { and need for assistance to adults and or peers. }\end{array}$ & 0 & 0 & 1 & 0 & 14 & 20 & 31 & 4.21 & .89 \\
\hline $\begin{array}{l}\text { ID When in their usual group, this child's peers respond } \\
20 \text { appropriately to this child's communication of their } \\
\text { feelings and/or bids for assistance }\end{array}$ & 0 & 12 & 5 & 3 & 25 & 17 & 4 & 2.64 & 1.55 \\
\hline $\begin{array}{l}\text { ID When this child communicates their feelings and/or need for } \\
21 \text { assistance, educators respond sensitively and appropriately, } \\
\text { affirming the child's feelings and supporting the child's } \\
\text { agency by scaffolding rather than 'doing for' the child. }\end{array}$ & 0 & 0 & 0 & 0 & 1 & 26 & 39 & 4.58 & .53 \\
\hline $\begin{array}{l}\text { This child explores his/her cultural identity and learns } \\
\text { about the social world by engaging in cultural activities. }\end{array}$ & 5 & 4 & 0 & 2 & 26 & 20 & 9 & 3.40 & 1.19 \\
\hline $\begin{array}{l}\text { When this child is exploring his/her cultural identity, } \\
\text { educators notice and respond in ways that acknowledge and } \\
\text { respect this child's family and culture, and provide the child } \\
\text { with experiences and materials that assist them learn about } \\
\text { their community, reflect the child's cultural heritage and } \\
\text { culturally valued ways of learning }\end{array}$ & 2 & 5 & 5 & 2 & 10 & 17 & 25 & 3.63 & 1.59 \\
\hline $\begin{array}{l}\text { ID Educators respect and build on this child's family's child- } \\
24 \text { rearing practices }\end{array}$ & 0 & 0 & 0 & 0 & 0 & 7 & 59 & 4.89 & .31 \\
\hline
\end{tabular}




\begin{tabular}{|c|c|c|c|c|c|c|c|c|c|c|}
\hline & & Freque & $\operatorname{cies}(1$ & & & & & & & \\
\hline Item & & $\begin{array}{l}\text { Not } \\
\text { ob- } \\
\text { serve } \\
\text { d }\end{array}$ & $\begin{array}{c}0 \\
\text { Not } \\
\text { yet }\end{array}$ & $\begin{array}{c}1 \\
\text { Rarel } \\
y\end{array}$ & 2 & $\begin{array}{l}3 \\
\text { Some } \\
- \\
\text { times }\end{array}$ & 4 & $\begin{array}{c}5 \\
\text { Alwa } \\
\text { ys }\end{array}$ & Mean & $\mathrm{SD}$ \\
\hline $\begin{array}{l}\mathrm{CO} \\
\mathrm{N} 01\end{array}$ & $\begin{array}{l}\text { When this child is engaged in play, this child's peers } \\
\text { respond with interest }\end{array}$ & 0 & 0 & 3 & 3 & 27 & 24 & 9 & 3.50 & .95 \\
\hline $\begin{array}{l}\mathrm{CO} \\
\mathrm{N} \\
02\end{array}$ & $\begin{array}{l}\text { When another child or group of children is near this child or } \\
\text { engaged in something this child notices, this child shows } \\
\text { interest in the other children }\end{array}$ & 0 & 0 & 0 & 1 & 24 & 23 & 18 & 3.88 & .83 \\
\hline $\begin{array}{l}\mathrm{CO} \\
\mathrm{N} \\
03\end{array}$ & $\begin{array}{l}\text { This child approaches and joins in when a group of } \\
\text { children is forming or interacting around a meal table, an } \\
\text { educator or an activity }\end{array}$ & 0 & 1 & 1 & 4 & 7 & 23 & 30 & 4.12 & 1.09 \\
\hline $\begin{array}{l}\mathrm{CO} \\
\mathrm{N} \\
04\end{array}$ & When another child is crying, this child shows concern & 3 & 3 & 11 & 5 & 24 & 12 & 8 & 2.87 & 1.39 \\
\hline $\begin{array}{l}\mathrm{CO} \\
\mathrm{N} \\
05\end{array}$ & When another child is crying, this child shows empathy & 3 & 11 & 8 & 3 & 20 & 15 & 6 & 2.60 & 1.62 \\
\hline $\begin{array}{l}\mathrm{CO} \\
\mathrm{N} \\
06\end{array}$ & $\begin{array}{l}\text { When this child initiates a socially positive interaction with } \\
\text { another child or group of children, the child's peers accept } \\
\text { this and respond positively }\end{array}$ & 0 & 4 & 3 & 1 & 26 & 27 & 5 & 3.27 & 1.18 \\
\hline $\begin{array}{l}\mathrm{CO} \\
\mathrm{N} \\
07\end{array}$ & $\begin{array}{l}\text { When another child or group of children initiate(s) a } \\
\text { socially positive interaction, this child accepts this and } \\
\text { responds positively }\end{array}$ & 0 & 1 & 1 & 4 & 23 & 24 & 13 & 3.62 & 1.02 \\
\hline $\begin{array}{l}\mathrm{CO} \\
\mathrm{N} \\
08\end{array}$ & $\begin{array}{l}\text { When this child initiates a socially negative interaction with } \\
\text { another child or group of children, educators intervene or } \\
\text { explain rules, explain how others feel in ways that are } \\
\text { respectful of this child }\end{array}$ & 1 & 2 & 2 & 2 & 4 & 10 & 45 & 4.35 & 1.24 \\
\hline
\end{tabular}




\begin{tabular}{|c|c|c|c|c|c|c|c|c|c|c|}
\hline & & & & & & & & & & \\
\hline $\begin{array}{l}\mathrm{CO} \\
\mathrm{N} \\
09\end{array}$ & $\begin{array}{l}\text { When another child or group of children initiate(s) a } \\
\text { socially negative interaction with this child, this child } \\
\text { defends self without escalating the conflict }\end{array}$ & 0 & 8 & 12 & 8 & 21 & 11 & 6 & 2.50 & 1.50 \\
\hline $\begin{array}{l}\mathrm{CO} \\
\mathrm{N} \\
10\end{array}$ & $\begin{array}{l}\text { When this child's peer(s) initiate(s) a socially negative } \\
\text { interaction with this child, this child cries, screams or } \\
\text { escalates the conflict }\end{array}$ & 0 & 2 & 7 & 7 & 24 & 16 & 10 & 3.14 & 1.29 \\
\hline $\begin{array}{l}\mathrm{CO} \\
\mathrm{N} \\
11\end{array}$ & $\begin{array}{l}\text { When educators work together with this child, this child } \\
\text { anticipates what needs to be done and collaborates }\end{array}$ & 0 & 0 & 3 & 1 & 10 & 32 & 20 & 3.98 & .97 \\
\hline $\begin{array}{l}\mathrm{CO} \\
\mathrm{N} \\
12\end{array}$ & $\begin{array}{l}\text { When this child is working together with educators in } \\
\text { routine care activities, educators anticipate this child's } \\
\text { uniqueness and individuality }\end{array}$ & 0 & 0 & 0 & 1 & 9 & 19 & 37 & 4.39 & .78 \\
\hline $\begin{array}{l}\mathrm{CO} \\
\mathrm{N} \\
13\end{array}$ & $\begin{array}{l}\text { When educators work together with this child alone or with } \\
\text { a group of children, this child attends and responds }\end{array}$ & 0 & 0 & 1 & 2 & 12 & 30 & 21 & 4.03 & .88 \\
\hline $\begin{array}{l}\mathrm{CO} \\
\mathrm{N} \\
14\end{array}$ & $\begin{array}{l}\text { When this child is attending to or responding to educators' } \\
\text { ideas or questions, educators respond in ways that } \\
\text { acknowledge this child's individual contribution }\end{array}$ & 0 & 2 & 1 & 0 & 8 & 17 & 38 & 4.29 & 1.12 \\
\hline $\begin{array}{l}\mathrm{CO} \\
\mathrm{N} \\
15\end{array}$ & $\begin{array}{l}\text { When educators are playing with this child, or are nearby } \\
\text { and available when this child is playing, this child seeks or } \\
\text { maintains the educator(s)' involvement or seeks help }\end{array}$ & 0 & 0 & 2 & 4 & 20 & 22 & 18 & 3.76 & 1.02 \\
\hline $\begin{array}{l}\mathrm{CO} \\
\mathrm{N} \\
16\end{array}$ & $\begin{array}{l}\text { When this child is playing with educators, educators } \\
\text { respond in ways that acknowledge this child's strengths } \\
\text { and interests }\end{array}$ & 0 & 0 & 0 & 1 & 2 & 18 & 45 & 4.62 & .63 \\
\hline
\end{tabular}


Emotional wellbeing items

\begin{tabular}{|c|c|c|c|c|c|c|c|c|c|c|}
\hline & & Freque & $\operatorname{cics}(\mathrm{n}$ & & & & & & & \\
\hline Item & & $\begin{array}{l}\text { Not } \\
\text { ob- } \\
\text { serve } \\
\text { d }\end{array}$ & $\begin{array}{c}0 \\
\text { Not } \\
\text { yet }\end{array}$ & $\begin{array}{c}1 \\
\text { Rarel } \\
y\end{array}$ & 2 & $\begin{array}{l}3 \\
\text { Some } \\
- \\
\text { times }\end{array}$ & 4 & $\begin{array}{l}5 \\
\text { Alwa } \\
\text { ys }\end{array}$ & Mean & SD \\
\hline $\begin{array}{l}\text { EM } \\
01\end{array}$ & $\begin{array}{l}\text { When this child is experiencing negative emotion(s), they } \\
\text { have clear ways of showing these emotions that are easy to } \\
\text { interpret }\end{array}$ & 0 & 0 & 1 & 1 & 8 & 21 & 35 & 4.33 & .87 \\
\hline $\begin{array}{l}\text { EM } \\
02\end{array}$ & $\begin{array}{l}\text { When this child is experiencing positive emotion(s), they } \\
\text { have clear ways of showing these emotions that are easy to } \\
\text { interpret }\end{array}$ & 0 & 0 & 0 & 0 & 5 & 21 & 40 & 4.53 & .64 \\
\hline $\begin{array}{l}\text { EM } \\
03\end{array}$ & $\begin{array}{l}\text { When this child is upset they have one or more self- } \\
\text { soothing strategies }\end{array}$ & 0 & 4 & 4 & 4 & 20 & 16 & 18 & 3.42 & 1.43 \\
\hline $\begin{array}{l}\text { EM } \\
04\end{array}$ & $\begin{array}{l}\text { When this child is upset they seek support from an } \\
\text { educator }\end{array}$ & 0 & 0 & 1 & 1 & 7 & 20 & 37 & 4.38 & .86 \\
\hline $\begin{array}{l}\text { EM } \\
05\end{array}$ & When this child is upset they seek support from a peer & 2 & 22 & 14 & 5 & 15 & 7 & 1 & 1.59 & 1.51 \\
\hline $\begin{array}{l}\text { EM } \\
06\end{array}$ & $\begin{array}{l}\text { When this child is upset, this child is able to calm relatively } \\
\text { quickly by using self-soothing or support from an } \\
\text { educator }\end{array}$ & 0 & 1 & 3 & 1 & 16 & 32 & 13 & 3.73 & 1.05 \\
\hline $\begin{array}{l}\text { EM } \\
07\end{array}$ & $\begin{array}{l}\text { When this child is experiencing emotions, or observing } \\
\text { emotions in others, this child uses some words to describe } \\
\text { their own feelings or the feelings of others }\end{array}$ & 0 & 30 & 5 & 6 & 14 & 8 & 3 & 1.61 & 1.70 \\
\hline
\end{tabular}




\begin{tabular}{|c|c|c|c|c|c|c|c|c|c|c|}
\hline & & Fre & icie & & & & & & & \\
\hline $\begin{array}{l}\text { EM } \\
08\end{array}$ & $\begin{array}{l}\text { When a preferred activity is going well or when something } \\
\text { novel and positive happens in the environment, this child } \\
\text { shows energy, happiness, or excitement }\end{array}$ & 0 & 1 & 0 & 2 & 14 & 17 & 32 & 4.15 & 1.03 \\
\hline $\begin{array}{l}\text { EM } \\
09\end{array}$ & $\begin{array}{l}\text { When this child shows emotions, the emotional expression } \\
\text { does not seem to match the circumstances }\end{array}$ & 20 & 5 & 32 & 5 & 3 & 0 & 1 & 1.22 & .89 \\
\hline $\begin{array}{l}\text { EM } \\
10\end{array}$ & $\begin{array}{l}\text { When this child is in their usual group, the child's peers } \\
\text { seem to read the emotional cues of the child well and } \\
\text { respond with an attempt at support }\end{array}$ & 4 & 13 & 4 & 2 & 27 & 14 & 2 & 2.50 & 1.52 \\
\hline $\begin{array}{l}\text { EM } \\
11\end{array}$ & $\begin{array}{l}\text { When in their usual group, this child shows they } \\
\text { understand the emotions of other children or their } \\
\text { educators, by matching facial expressions, showing } \\
\text { concern, becoming upset when others are upset etc }\end{array}$ & 1 & 6 & 7 & 8 & 30 & 8 & 6 & 2.69 & 1.35 \\
\hline $\begin{array}{l}\text { EM } \\
12\end{array}$ & $\begin{array}{l}\text { When this child is upset, educators have ways to soothe the } \\
\text { child that match with this child's preferences }\end{array}$ & 0 & 0 & 0 & 0 & 5 & 14 & 47 & 4.64 & .62 \\
\hline $\begin{array}{l}\text { EM } \\
13\end{array}$ & $\begin{array}{l}\text { When this child is upset, and educators make an attempt to } \\
\text { soothe this child, soothing is successful within a relatively } \\
\text { short period of time }\end{array}$ & 0 & 0 & 2 & 0 & 8 & 21 & 35 & 4.32 & .91 \\
\hline $\begin{array}{l}\text { EM } \\
14\end{array}$ & $\begin{array}{l}\text { When this child is expressing emotions (facial expression, } \\
\text { bodily movement, actions), educators use words with this } \\
\text { child to describe the child's feelings }\end{array}$ & 1 & 0 & 0 & 0 & 1 & 22 & 42 & 4.63 & .52 \\
\hline $\begin{array}{l}\text { EM } \\
15\end{array}$ & $\begin{array}{l}\text { When this child is expressing emotions (facial expression, } \\
\text { bodily movement, actions), educators use facial expression } \\
\text { and sounds to reflect the child's feelings }\end{array}$ & 0 & 0 & 1 & 0 & 17 & 25 & 23 & 4.05 & .87 \\
\hline $\begin{array}{l}\text { EM } \\
16\end{array}$ & $\begin{array}{l}\text { When this child is expressing emotions (facial expression, } \\
\text { bodily movement, actions), educators talk about the }\end{array}$ & 1 & 0 & 4 & 1 & 20 & 20 & 20 & 3.78 & 1.10 \\
\hline
\end{tabular}


Frequencies (n)

feelings of peers and book characters etc in the learning environment

EM This child's key triggers in terms of becoming distressed are well known by the educators

EM Educators take steps to support the child at these trigger

0

0

0

4

26

36

4.48

18 times in ways that match the child's preferences and allow time for emotional distress to resolve

EM If this child's caregivers communicate about the child's

19 feelings and share information about particularly upsetting or positive emotions felt by the child, educators use this information to help interpret and support the child's emotional expressions at the service 


\begin{tabular}{|c|c|c|c|c|c|c|c|c|c|c|}
\hline & & Frequ & $\operatorname{cies}(\mathrm{n}$ & & & & & & & \\
\hline Item & & $\begin{array}{l}\text { Not } \\
\text { ob- } \\
\text { serve } \\
\text { d }\end{array}$ & $\begin{array}{c}0 \\
\text { Not } \\
\text { yet }\end{array}$ & $\begin{array}{c}1 \\
\text { Rarel } \\
y\end{array}$ & 2 & $\begin{array}{l}3 \\
\text { Some } \\
- \\
\text { times }\end{array}$ & 4 & $\begin{array}{c}5 \\
\text { Alwa } \\
\text { ys }\end{array}$ & Mean & SD \\
\hline PH01 & $\begin{array}{l}\text { When materials are available for active physical play, this } \\
\text { child engages in active whole body movement }\end{array}$ & 0 & 0 & 0 & 0 & 10 & 20 & 36 & 4.39 & .74 \\
\hline PH02 & $\begin{array}{l}\text { When this child indicates an interest in engaging in active } \\
\text { whole body movement play, educators respond in ways } \\
\text { that acknowledge this child's efforts }\end{array}$ & 0 & 0 & 0 & 2 & 9 & 16 & 39 & 4.39 & .84 \\
\hline PH03 & $\begin{array}{l}\text { When this child indicates an interest in engaging in active } \\
\text { whole body movement play, educators join in to } \\
\text { encourage participation or teach a skill }\end{array}$ & 0 & 0 & 0 & 0 & 18 & 21 & 27 & 4.14 & .82 \\
\hline PH04 & $\begin{array}{l}\text { When educators invite this child to join in or engage in } \\
\text { active whole body movement play with her/him, this } \\
\text { child participates }\end{array}$ & 0 & 0 & 1 & 0 & 14 & 30 & 21 & 4.06 & .82 \\
\hline PH05 & $\begin{array}{l}\text { When materials are available for active physical play, this } \\
\text { child engages in large motor arm and/or leg movements }\end{array}$ & 0 & 0 & 0 & 0 & 16 & 28 & 22 & 4.09 & .76 \\
\hline PH06 & $\begin{array}{l}\text { When this child indicates an interest in engaging in active } \\
\text { large motor arm and/or leg movement play, educators } \\
\text { respond in ways that acknowledge this child's efforts }\end{array}$ & 0 & 0 & 0 & 0 & 6 & 17 & 43 & 4.56 & .66 \\
\hline PH07 & $\begin{array}{l}\text { When this child indicates an interest in engaging in active } \\
\text { large motor arm and/or leg movement play, educators } \\
\text { join in to encourage participation or teach a skill }\end{array}$ & 0 & 0 & 0 & 0 & 9 & 27 & 30 & 4.32 & .71 \\
\hline PH08 & $\begin{array}{l}\text { When educators invite this child to join in or engage in } \\
\text { active arm/leg movement play with them, this child } \\
\text { participates }\end{array}$ & 0 & 2 & 1 & 0 & 17 & 23 & 23 & 3.92 & 1.11 \\
\hline
\end{tabular}




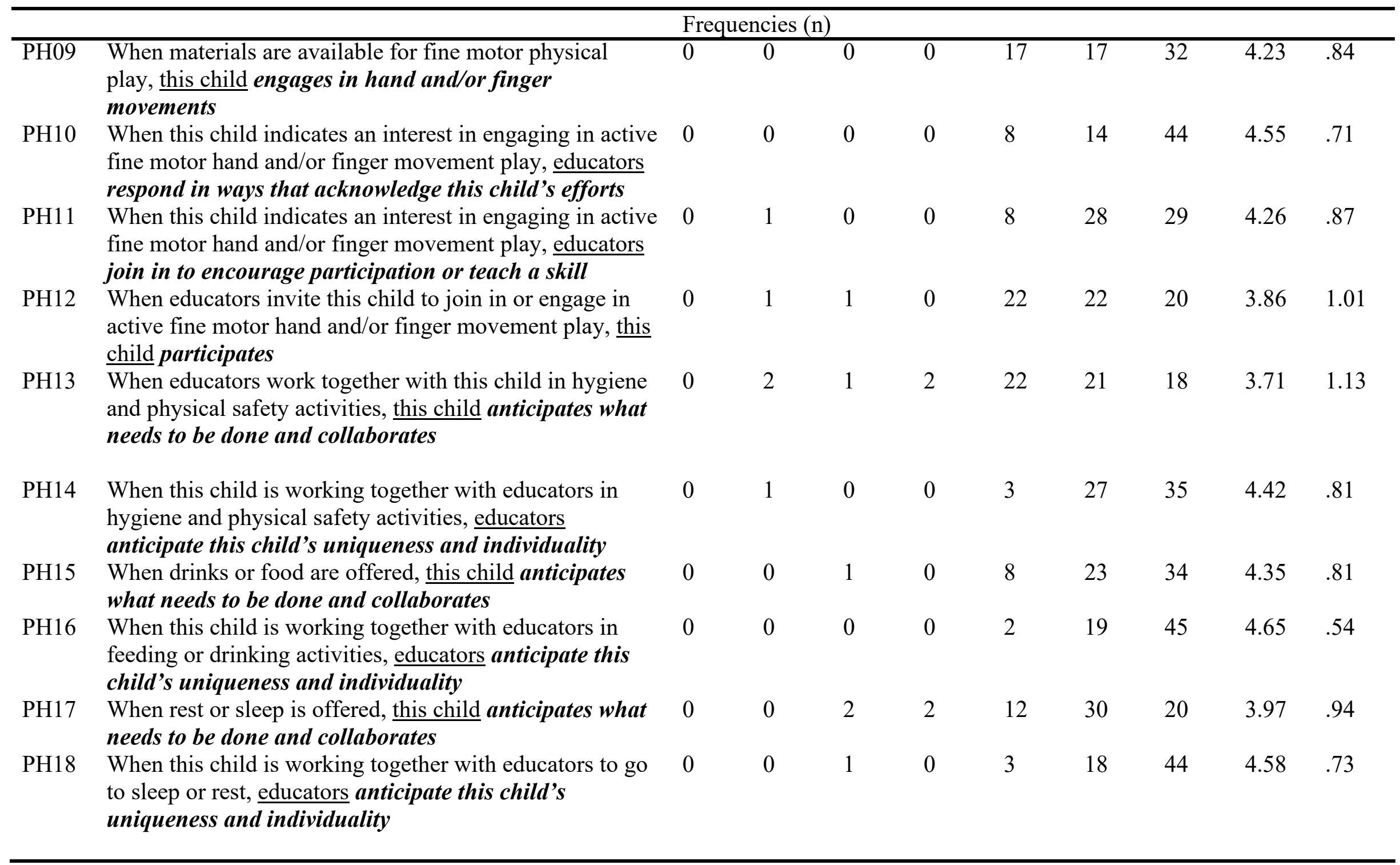




\begin{tabular}{|c|c|c|c|c|c|c|c|c|c|c|}
\hline & & & $\mathrm{ci}$ & & & & & & & \\
\hline PH19 & $\begin{array}{l}\text { When this child is tired he/she has some easy-to-read } \\
\text { cues that tell educators he/she is tired }\end{array}$ & 0 & 0 & 1 & 0 & 8 & 31 & 26 & 4.23 & .78 \\
\hline PH20 & $\begin{array}{l}\text { When rest or sleep is offered, this child has some self- } \\
\text { soothing strategies to use } \\
\text { (e.g. thumb suck, favourite toy etc) }\end{array}$ & 6 & 0 & 4 & 1 & 11 & 18 & 26 & 4.02 & 1.14 \\
\hline PH21 & $\begin{array}{l}\text { When rest or sleep is offered, this child can transition } \\
\text { from awake to asleep or resting and calm on their own }\end{array}$ & 0 & 0 & 7 & 3 & 16 & 27 & 13 & 3.55 & 1.18 \\
\hline PH22 & $\begin{array}{l}\text { When this child wakes from a rest or sleep they are } \\
\text { generally refreshed and calm }\end{array}$ & 0 & 0 & 0 & 1 & 13 & 35 & 17 & 4.03 & .72 \\
\hline PH23 & $\begin{array}{l}\text { When this child is tired, educators offer sleep and rest } \\
\text { that balances the child's needs with the routines of the } \\
\text { room }\end{array}$ & 0 & 0 & 0 & 0 & 2 & 26 & 38 & 4.55 & .56 \\
\hline PH24 & $\begin{array}{l}\text { When rest or sleep is offered, educators have ways to co- } \\
\text { soothe with this child (that are matched to the child's } \\
\text { preferences and usually effective }\end{array}$ & 0 & 1 & 0 & 1 & 6 & 15 & 42 & 4.46 & .92 \\
\hline $\mathrm{PH} 25$ & $\begin{array}{l}\text { If parents share information about sleep preferences for } \\
\text { children (timing, duration etc), educators use this } \\
\text { information to adjust rest and sleep routines and actions } \\
\text { to align with parent and child sleep preferences. }\end{array}$ & 0 & 0 & 0 & 0 & 0 & 15 & 51 & 4.77 & .42 \\
\hline
\end{tabular}




\begin{tabular}{|c|c|c|c|c|c|c|c|c|c|c|}
\hline & & Freque & acies (1 & & & & & & & \\
\hline Item & & $\begin{array}{l}\text { Not } \\
\text { ob- } \\
\text { serve } \\
\text { d }\end{array}$ & $\begin{array}{l}0 \\
\text { Not } \\
\text { yet }\end{array}$ & $\begin{array}{c}1 \\
\text { Rarel } \\
y\end{array}$ & 2 & $\begin{array}{l}3 \\
\text { Some } \\
- \\
\text { times }\end{array}$ & 4 & $\begin{array}{l}5 \\
\text { Alwa } \\
\text { ys }\end{array}$ & Mean & $\mathrm{SD}$ \\
\hline $\begin{array}{l}\text { CK0 } \\
1\end{array}$ & $\begin{array}{l}\text { This child's efforts to engage with their environment } \\
\text { (materials, activities, educators, and peers) show } \\
\text { involvement and enthusiasm }\end{array}$ & 0 & 2 & 1 & 1 & 15 & 23 & 24 & 3.94 & 1.14 \\
\hline $\begin{array}{l}\text { CK0 } \\
2\end{array}$ & $\begin{array}{l}\text { When this child asks for help from educators with learning } \\
\text { experiences educators respond in ways that match the } \\
\text { child's needs and strengths }\end{array}$ & 0 & 0 & 0 & 1 & 0 & 25 & 40 & 4.58 & .58 \\
\hline $\begin{array}{l}\text { CK0 } \\
3\end{array}$ & $\begin{array}{l}\text { This child's efforts to engage with their environment } \\
\text { (materials, activities, educators, and peers) show curiosity }\end{array}$ & 0 & 0 & 0 & 0 & 13 & 25 & 28 & 4.23 & .76 \\
\hline $\begin{array}{l}\text { CK0 } \\
4\end{array}$ & $\begin{array}{l}\text { This child's efforts to engage with their environment } \\
\text { (materials, activities, educators, and peers) show their } \\
\text { persistence }\end{array}$ & 0 & 1 & 0 & 1 & 33 & 23 & 8 & 3.53 & .85 \\
\hline $\begin{array}{l}\text { CK0 } \\
5\end{array}$ & $\begin{array}{l}\text { This child's efforts to engage with their environment } \\
\text { (materials, activities, educators, and peers) show creativity } \\
\text { and imagination }\end{array}$ & 0 & 4 & 3 & 5 & 29 & 14 & 11 & 3.20 & 1.29 \\
\hline $\begin{array}{l}\text { CK0 } \\
6\end{array}$ & $\begin{array}{l}\text { When this child engages with the learning environment } \\
\text { (materials, activities, educators, and peers), educators } \\
\text { respond in ways that acknowledge and encourage this } \\
\text { child's efforts }\end{array}$ & 0 & 0 & 0 & 0 & 5 & 20 & 41 & 4.55 & .64 \\
\hline $\begin{array}{l}\text { CK0 } \\
7\end{array}$ & $\begin{array}{l}\text { When this child engages with the learning environment } \\
\text { (materials, activities, educators, and peers), educators } \\
\text { commentate or describe what's going on }\end{array}$ & 0 & 0 & 0 & 0 & 12 & 29 & 25 & 4.20 & .73 \\
\hline
\end{tabular}




\begin{tabular}{|c|c|c|c|c|c|c|c|c|c|c|}
\hline & & & icie & & & & & & & \\
\hline $\begin{array}{l}\text { CK0 } \\
8\end{array}$ & $\begin{array}{l}\text { When this child engages with the learning environment } \\
\text { (materials, activities, educators, and peers), educators use } \\
\text { intentional teaching to enable children to engage in co- } \\
\text { constructing understanding }\end{array}$ & $\overline{0}$ & 0 & 0 & 0 & 9 & 26 & 31 & 4.33 & .71 \\
\hline $\begin{array}{l}\text { CK0 } \\
9\end{array}$ & $\begin{array}{l}\text { This child's efforts to engage with their environment } \\
\text { (materials, activities, educators, and peers) show elements } \\
\text { of cooperative learning skills }\end{array}$ & 1 & 4 & 7 & 5 & 23 & 22 & 4 & 2.98 & 1.29 \\
\hline $\begin{array}{l}\text { CK1 } \\
0\end{array}$ & $\begin{array}{l}\text { When this child displays emerging cooperative learning } \\
\text { skills, educators provide guidance and support }\end{array}$ & 1 & 0 & 0 & 0 & 3 & 29 & 33 & 4.46 & .59 \\
\hline $\begin{array}{l}\text { CK1 } \\
1\end{array}$ & $\begin{array}{l}\text { This child's efforts to engage with their environment } \\
\text { (materials, activities, educators, and peers) show } \\
\text { increasingly coordinated goal-oriented behaviours and } \\
\text { skills mastery }\end{array}$ & 0 & 1 & 2 & 3 & 23 & 19 & 18 & 3.68 & 1.11 \\
\hline $\begin{array}{l}\text { CK1 } \\
2\end{array}$ & $\begin{array}{l}\text { When this child engages with resources that are available } \\
\text { within their environment (materials, activities, educators, } \\
\text { and peers), this child uses processes of problem-solving } \\
\text { and experimentation }\end{array}$ & 0 & 0 & 6 & 6 & 18 & 18 & 18 & 3.55 & 1.24 \\
\hline $\begin{array}{l}\text { CK1 } \\
3\end{array}$ & $\begin{array}{l}\text { When this child engages with resources that are available } \\
\text { within their environment (materials, activities, educators, } \\
\text { and peers), this child uses processes of hypothesising and } \\
\text { inferring }\end{array}$ & 1 & 13 & 5 & 3 & 25 & 12 & 7 & 2.60 & 1.63 \\
\hline $\begin{array}{l}\text { CK1 } \\
4\end{array}$ & $\begin{array}{l}\text { This child's efforts to engage with their environment } \\
\text { (materials, activities, educators, and peers) show } \\
\text { anticipation of familiar events }\end{array}$ & 0 & 5 & 2 & 3 & 17 & 27 & 12 & 3.44 & 1.35 \\
\hline $\begin{array}{l}\text { CK1 } \\
5\end{array}$ & $\begin{array}{l}\text { When this child engages with their environment (materials, } \\
\text { activities, educators, and peers), this child remembers and } \\
\text { mimics actions with a time lapse in between }\end{array}$ & 2 & 9 & 2 & 2 & 19 & 22 & 10 & 3.14 & 1.55 \\
\hline $\begin{array}{l}\text { CK1 } \\
6\end{array}$ & $\begin{array}{l}\text { When this child engages with their environment (materials, } \\
\text { activities, educators, and peers), this child remembers }\end{array}$ & 3 & 7 & 7 & 3 & 24 & 16 & 6 & 2.84 & 1.46 \\
\hline
\end{tabular}


Frequencies (n)

connections between cause and effect and transfers those

connections to a new situation

CK1 When this child engages with their environment (materials, 1 activities, educators, and peers), this child represents or symbolises objects in different ways

CK1 When this child engages with their environment (materials, 0 activities, educators, and peers), educators use child interests in planning of resources and activities to extend this child's learning. 


\begin{tabular}{|c|c|c|c|c|c|c|c|c|c|c|}
\hline & & Freque & cies $(n$ & & & & & & & \\
\hline Item & & $\begin{array}{l}\text { Not } \\
\text { ob- } \\
\text { serve } \\
\text { d }\end{array}$ & $\begin{array}{l}0 \\
\text { Not } \\
\text { yet }\end{array}$ & $\begin{array}{c}1 \\
\text { Rarel } \\
y\end{array}$ & 2 & $\begin{array}{l}3 \\
\text { Some } \\
- \\
\text { times }\end{array}$ & 4 & $\begin{array}{l}5 \\
\text { Alwa } \\
\text { ys }\end{array}$ & Mean & SD \\
\hline $\begin{array}{l}\mathrm{CO} 0 \\
1\end{array}$ & $\begin{array}{l}\text { When this child initiates communication, educators listen } \\
\text { and respond in ways that acknowledge and encourage } \\
\text { this child's efforts and ideas }\end{array}$ & 0 & 2 & 0 & 0 & 1 & 12 & 51 & 4.64 & .94 \\
\hline $\begin{array}{l}\mathrm{CO} 0 \\
2\end{array}$ & $\begin{array}{l}\text { When educators communicate verbally or nonverbally with } \\
\text { this child, he/she listens and responds by communicating } \\
\text { or collaborating }\end{array}$ & 0 & 2 & 2 & 1 & 8 & 31 & 22 & 3.97 & 1.14 \\
\hline $\begin{array}{l}\mathrm{CO} 0 \\
3\end{array}$ & $\begin{array}{l}\text { When this child initiates communication with other } \\
\text { children, this child's peers listen and respond by } \\
\text { communicating with this child }\end{array}$ & 0 & 0 & 11 & 6 & 22 & 20 & 7 & 3.09 & 1.22 \\
\hline $\begin{array}{l}\mathrm{CO} 0 \\
4\end{array}$ & $\begin{array}{l}\text { When another child initiates communication with this } \\
\text { child, this child listens and responds by communicating } \\
\text { with the other child/ren }\end{array}$ & 0 & 2 & 9 & 6 & 21 & 21 & 7 & 3.08 & 1.29 \\
\hline $\begin{array}{l}\mathrm{CO} 0 \\
5\end{array}$ & $\begin{array}{l}\text { When another child communicates, vocalizes or speaks to } \\
\text { this child, this child shows she/he understands what was } \\
\text { said }\end{array}$ & 0 & 7 & 7 & 3 & 15 & 25 & 9 & 3.08 & 1.54 \\
\hline $\begin{array}{l}\mathrm{CO} 0 \\
6\end{array}$ & $\begin{array}{l}\text { When educators speak to this child, this child shows he/she } \\
\text { understands what was said }\end{array}$ & 0 & 4 & 3 & 3 & 11 & 24 & 21 & 3.68 & 1.41 \\
\hline $\begin{array}{l}\mathrm{CO} 0 \\
7\end{array}$ & $\begin{array}{l}\text { When this child communicates, vocalizes or speaks with } \\
\text { another child/ren, this child's peers show they understand } \\
\text { what this child is saying }\end{array}$ & 0 & 12 & 5 & 5 & 16 & 24 & 4 & 2.71 & 1.61 \\
\hline
\end{tabular}


Frequencies (n)

CO0 When this child communicates, vocalizes or speaks with

8 educators, educators understand what this child is

0

6

2

0

15

23

$20 \quad 3.62 \quad 1.47$

saying/communicating

CO0 When this child is playing alone, this child engages in self- 2 talk

CO1 When this child is engaging in self-talk while playing,

$0 \quad$ educators listen and don't interfere

CO1 When materials or activities are available or provided for

1 oral language or singing, this child engages in the experience

CO1 When this child engages with oral language or singing

2 experiences, educators notice and respond in ways that acknowledge and encourage this child's efforts and ideas

CO1 When materials or activities are available or provided for

3 mark-making, drawing or writing, this child engages in the experience

CO1 When this child engages with mark-making, drawing or

4 writing experiences, educators notice and respond in ways that acknowledge and encourage this child's efforts and ideas

CO1 When text-based materials (books, posters, names on

5 pictures) are available, this child shows interest, notices, points to, touches or vocalises about the text

CO1 When this child engages with text-based play or

0

2

$4 \quad 7$

3

24

18

8

$3.08 \quad 1.36$

0

0

10

23

28

$4.09 \quad 1.17$

0

3

3

14

16

25

0

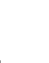

0

5

$\begin{array}{cccccccc}4 & 0 & 0 & 6 & 19 & 37 & 4.23 & 1.26 \\ 5 & 4 & 2 & 18 & 20 & 17 & 3.44 & 1.46\end{array}$

6 experiences, educators notice and respond in ways that acknowledge and encourage this child's efforts and ideas

$\begin{array}{lllllllll}0 & 5 & 4 & 3 & 20 & 18 & 16 & 3.36 & 1.45 \\ 3 & 2 & 0 & 0 & 1 & 23 & 37 & 4.44 & .96\end{array}$


